\title{
Synthesis, Characterisation and DNA Binding Studies of Metal Complexes of Norfloxacin
}

\author{
S. PUSHPALATHA \\ Department of Chemistry, Noorul Islam University, \\ Kumaracoil, KK Dist, Tamilnadu, 629180, India \\ pushpa07latha@gmail.com
}

Received 11 October 2015 / Accepted 28 October 2015

\begin{abstract}
Metal complexes of tioconazole such as $\left[\mathrm{Cu}(\text { nor })_{2}\left(\mathrm{H}_{2} \mathrm{O}\right)_{2}\right], \quad\left[\mathrm{Zn}(\text { nor })_{2}\left(\mathrm{H}_{2} \mathrm{O}\right)_{2}\right]$, $\left[\mathrm{Ni}(\text { nor })_{2}\left(\mathrm{H}_{2} \mathrm{O}\right)_{2}\right] .4 \mathrm{H}_{2} \mathrm{O}$ and $\left[\mathrm{Fe}(\text { nor })_{2}\left(\mathrm{H}_{2} \mathrm{O}\right) \mathrm{Cl}\right] .5 \mathrm{H}_{2} \mathrm{O}$ have been synthesized and characterised by elemental analysis, IR, UV-Visibe, ESR, NMR, XRD spectrscopic techniques. Thermal analysis was studied by TGA, DSC method. Morphological studies were carried out by scanning electron microscopic method. DNA binding studies were carried out by viscosity method. From the spectral studies an octahedral geometry was proposed for the copper complex. Prepared complexes showed enhanced DNA binding tendency than the parent drug that might be of interest for future research.
\end{abstract}

Keywords: Metal complexes, DNA binding studies, Viscosity method, Ligand

\section{Introduction}

Norfloxacin(1-ethyl-6-fluoro-4-oxo-7-piperazin-1-yl-1- $H$-quinolinecarboxylic acid) belongs to fluoroquinolones and is a wide-ranging drug used in treating bacterial infections of the urinary tract, respiratory tract and the skin. It is also known that NOR can be effective in treating diarrhoea and could treat conjunctivitis when it was administered in the form of eye drops. Norfloxacin is not effective against infections involving anaerobic bacteria (e.g. yeast, athlete's foot) ${ }^{1-5}$. Quinolone antibiotics could participate in the formation of complexes in a number of ways ${ }^{6-9}$. In acidic media, quinolones are usually singly or doubly protonated making them unable to coordinate to the metal cations and, in such cases, only electrostatic interaction are observed between the drug and the metal ions ${ }^{10-12}$. It is found that neutral quinolones in the zwitterionic state are capable of forming simple complexes (bidentate chelating $)^{13-14}$. The quinolones could also act as bridging ligands and are capable of forming polynuclear complexes ${ }^{15}$.

\section{Experimental}

\section{Synthesis of metal complexes}

Complexes with the general formula $\left[\mathrm{M}(\text { nor })_{2}\right] \mathrm{X}_{2} \cdot \mathrm{nH}_{2} \mathrm{O}$ synthesized, employing a $1: 2$ (metal ions:nor) ratio. A solution of $0.1 \mathrm{M}$ of a salt of each $\mathrm{Zn}(\mathrm{II}), \mathrm{Cu}(\mathrm{II}), \mathrm{Ni}$ (II) and $\mathrm{Fe}(\mathrm{III})$ 
previously dissolved in $10 \mathrm{~mL}$ of distilled water was added to a solution of $0.1 \mathrm{M}$ of norfloxacin in $20 \mathrm{~mL}$ of acetone. The resulting mixtures were heated to $50{ }^{\circ} \mathrm{C}$ under reflux on a water bath for about 2 hours and then cooled. The complexes obtained were separated from the reaction mixture by filtration, washed with boiling water and acetone and dried under vacuum over $\mathrm{CaCl}_{2}$. The complexes are formulated as $\left[\mathrm{Cu}(\text { nor })_{2}\left(\mathrm{H}_{2} \mathrm{O}\right)_{2}\right]$, $\left[\mathrm{Zn}(\text { nor })_{2}\left(\mathrm{H}_{2} \mathrm{O}\right)_{2}\right]$, [Ni(nor $\left.)_{2}\left(\mathrm{H}_{2} \mathrm{O}\right)_{2}\right] \cdot 4 \mathrm{H}_{2} \mathrm{O}$ and $\left[\mathrm{Fe}(\text { nor })_{2}\left(\mathrm{H}_{2} \mathrm{O}\right) \mathrm{Cl}\right] .5 \mathrm{H}_{2} \mathrm{O}$.

\section{Results and Discussion}

\section{IR spectrum}

The position and/or the intensities of the peaks in the drugs are expected to be changed upon chelation. The $v(\mathrm{OH}), v(\mathrm{C}=\mathrm{O}), v_{\text {asym }}(\mathrm{COO})$ and $v_{\text {sym }}(\mathrm{COO})$ stretching vibrations are observed at 3448, 1727, 1590 and $1396 \mathrm{~cm}^{-1}$ for free ligand respectively. The participation of the carboxylate oxygen atom in the complex formation is evidenced from the shift in position of these bands to $3276-3427,1709-1720 \mathrm{~cm}^{-1}$ or the disappearance of the bands between $1549 \mathrm{~cm}^{-1}-1591 \mathrm{~cm}^{-1}$ and $1381 \mathrm{~cm}^{-1}, 1394 \mathrm{~cm}^{-1}$ for drug-metal complexes. The carbonyl $v(C=O)$, stretching vibration is found in the free ligand at $1720 \mathrm{~cm}^{-1}$. This band is shifted to lower wave numbers $\left(1621 \mathrm{~cm}^{-1}, 1632 \mathrm{~cm}^{-1}\right)$ in the complexes indicating the participation of the carbonyl oxygen in coordination. New bands are found in the spectra of the complexes in the regions 524-555, 497-523 and 464-498 $\mathrm{nm}$ which are assigned to $v(\mathrm{M}-\mathrm{O})$ stretching vibrations of coordinated water, carboxylate-O and carbonyl-O, respectively ${ }^{16}$.

\section{Electronic spectrum}

The electronic spectra of the $\left[\mathrm{Cu}(\text { nor })_{2}\left(\mathrm{H}_{2} \mathrm{O}\right)_{2}\right]$ complex showed two low-energy weak bands at $660-630 \mathrm{~nm}$ and a strong high-energy band at 330-328 $\mathrm{nm}$. The low-energy band in this position is expected for an octahedral configuration and may be assigned to $10 \mathrm{Dq}$ corresponding to the transition ${ }^{2} \mathrm{Eg} \rightarrow{ }^{2} \mathrm{~T}_{2} \mathrm{~g}$. The strong high-energy band, in turn, is assigned to metal $\rightarrow$ ligand charge transfer. Also, the magnetic moment values (1.9-2.2 BM) for the copper(II) are indicative of antiferromagnetic spin-spin interaction through molecular association. Hence, the copper(II) complexes appear to be in the octahedral geometry with $\mathrm{d}_{\mathrm{x}-\mathrm{y}}^{2}$ ground state ${ }^{17}$. The $\mathrm{Zn}$ (II) complex showed no $\mathrm{d}-\mathrm{d}$ bands as is expected for a $\mathrm{d}^{10}$ system and was found to be diamagnetic in nature. On the basis of analytical, conductance and spectroscopic data, $\mathrm{Zn}$ (II) complex is assigned an octahedral geometry. The electronic spectrum of $\mathrm{Ni}(\mathrm{II})$ complex showed three bands at 622, 382 and 308-265 nm corresponding to the transitions ${ }^{3} \mathrm{~A}_{2 \mathrm{~g}}(\mathrm{~F}) \rightarrow{ }^{3} \mathrm{~T}_{2} \mathrm{~g}\left(v_{1}\right),{ }^{3} \mathrm{~A}_{2} \mathrm{~g}(\mathrm{~F}) \rightarrow{ }^{3} \mathrm{~T}_{1} \mathrm{~g}(\mathrm{~F})\left(v_{2}\right)$ and ${ }^{3} \mathrm{~A}_{2} \mathrm{~g}(\mathrm{~F}) \rightarrow{ }^{3} \mathrm{~T}_{1} \mathrm{~g}(\mathrm{P})\left(v_{3}\right)$. The magnetic moment of $\mathrm{Ni}(\mathrm{II})$ complex is lying within the range of 2.5-3.5 B.M for octahedral $\mathrm{Ni}(\mathrm{II})$ complexes $^{18}$. From the spectral data of the iron(III) complexes it can be seen that all of them exhibit one band at 508-568 nm which can be assigned to ${ }^{6} \mathrm{~A}_{1} \mathrm{~g} \rightarrow{ }^{4} \mathrm{~T}_{1} \mathrm{~g}$ transition characteristic of octahedral structure. The broad intense and poorly resolved bands between $320-450 \mathrm{~nm}$ may be assigned to MLCT ${ }^{19}$. The high intensity band below $320 \mathrm{~nm}$ is of ligand origin assignable to intraligand $\mathrm{n}-\pi / \pi-\pi^{*} \operatorname{transition}^{20}$.

\section{${ }^{1} H$ NMR spectrum}

The ${ }^{1} \mathrm{H}$ NMR spectrum further supports the assignment of the coordination modes. In the free ligand, the signal observed at $11 \mathrm{ppm}$ can be assigned to the carboxylate $-\mathrm{OH}$ group. This signal disappears in the spectrum of the $\left[\mathrm{Zn}(\text { nor })_{2}\left(\mathrm{H}_{2} \mathrm{O}\right)_{2}\right]$ complex, (Figure 1 ) which confirms the coordination of ligand to the $\mathrm{M}(\mathrm{II})$ ions through the deprotonated carboxylic $\mathrm{OH}$ group. The peak at $\delta 3.55 \mathrm{ppm}$ can be assigned as coming from the water molecules of 
crystallization, which were not detected in the spectrum of the free ligand. The protons of the $-\mathrm{CH}_{2}$ - group appears as a quartet at $\delta 4.80 \mathrm{ppm}$, while the $-\mathrm{CH}_{3}$ group (triplet) at $\delta 3.5$ ppm.

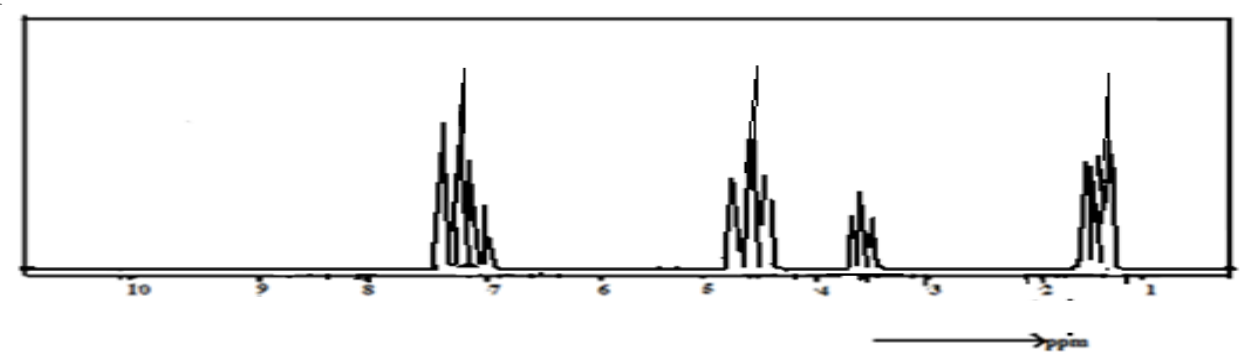

ESR spectrum

Figure 1. ${ }^{1} \mathrm{H}$ NMR spectrum $\left[\mathrm{Zn}(\text { nor })_{2}\left(\mathrm{H}_{2} \mathrm{O}\right)_{2}\right]$,

ESR spectrum of $\left[\mathrm{Cu}(\text { nor })_{2}\left(\mathrm{H}_{2} \mathrm{O}\right)_{2}\right]$ was studied under the magnetic field strength of $3000 \mathrm{G}$. The spectrum of complex shows an intense absorption in the high field and is isotropic due to tumbling motion of the molecule. The ' $\mathrm{g}$ ' values of the complex is $\mathrm{g}_{\|}(2.315)>\mathrm{g}_{\perp}(2.087)$ $>2.0023$, indicating that the unpaired electron in the ground state of $\mathrm{Cu}$ (II) ion is predominantly in $\mathrm{d}_{\mathrm{x}-\mathrm{y}}^{2}$. The value of exchange interaction term $\mathrm{G}$, estimated from the following expression is

$$
\mathrm{G}=\mathrm{g}_{\|}-2.0023 / \mathrm{g}_{\perp}-2.0023 \text {. }
$$

If $\mathrm{G}>4.0$, the local tetragonal axes are aligned parallel or only slightly misaligned. If $\mathrm{G}<4.0$, significant exchange coupling is present and misalignment is appreciable. The observed value for the exchange interaction term ' $G$ ' suggests that the complex has regular octahedral geometry ${ }^{21}$.

\section{XRD studies}

The XRD pattern of $\left[\mathrm{Zn}(\text { nor })_{2}\left(\mathrm{H}_{2} \mathrm{O}\right)_{2}\right]$ complex was studied in the $2 \theta$ range of $5-35^{\circ}$. The crystalline size of the complex was calculated from Scherer's formula. From the observed $\mathrm{d}_{\mathrm{XRD}}$ pattern, the average crystalline size for the metallo drug is found to be $28 \mathrm{~nm}$ indicating that it is in nanocrystalline in nature.

\section{TGA studies}

The TGA studies were carried out to explore the thermal stability of the complexes. The thermal behaviour of the metal complex was studied in the temperature range of $25-800{ }^{\circ} \mathrm{C}$. The TGA studies of complex $\left[\mathrm{Fe}(\text { nor })_{2}\left(\mathrm{H}_{2} \mathrm{O}\right) \mathrm{Cl}\right] .5 \mathrm{H}_{2} \mathrm{O}$ reveal that the decomposition proceeds in three steps. In the first stage weight loss at $118{ }^{\circ} \mathrm{C}$ corresponds to the presence of the lattice water. The weight loss in the temperature range $130-220{ }^{\circ} \mathrm{C}$ is due to the presence of the coordinated water in the complex. A plateau was obtained after heating above $600{ }^{\circ} \mathrm{C}$, which corresponds to the formation of stable metal oxide ${ }^{22,23}$. The specific decomposition fragments are $\mathrm{C}_{11} \mathrm{H}_{7} \mathrm{ON}_{3} \mathrm{~F}$ and $\mathrm{CuO}$.

\section{DSC studies}

DSC behaviour of the metal complex (Figure 2) has been studied in the temperature range of $0-300{ }^{\circ} \mathrm{C}$. The metal complex $\left[\mathrm{Fe}(\text { nor })_{2}\left(\mathrm{H}_{2} \mathrm{O}\right) \mathrm{Cl}\right] .5 \mathrm{H}_{2} \mathrm{O}$ shows the single $\mathrm{Tg}$ at $261.4{ }^{\circ} \mathrm{C}$. The copper complex shows a sharp endo thermal peak at $185.1{ }^{\circ} \mathrm{C}$ indicating the melting of the complex. The endothermic peak noted at $276.7^{\circ} \mathrm{C}$ can be attributed to the decomposition of the complex. Broad exothermic peak obtained at $330{ }^{\circ} \mathrm{C}$ and $391.6{ }^{\circ} \mathrm{C}$ can also be due to the decomposition of the complex ${ }^{24,25}$. 


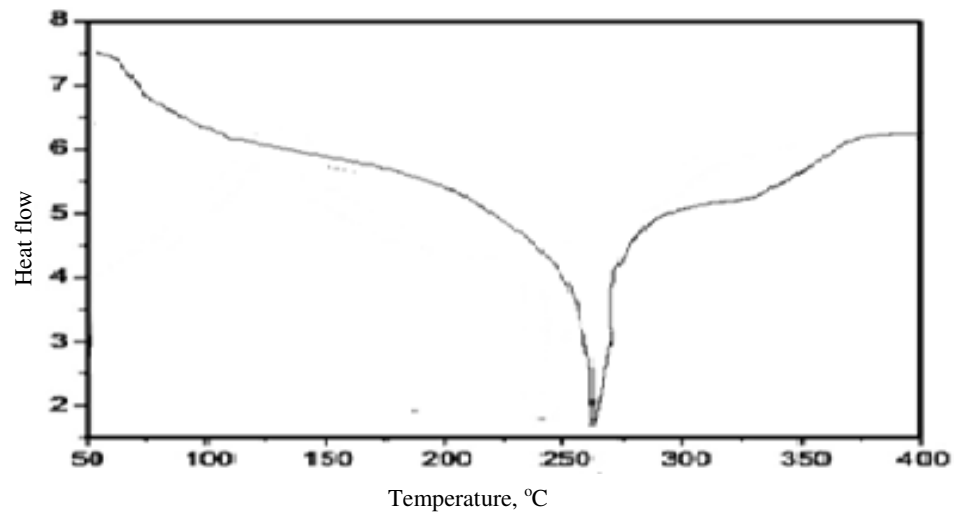

Figure 2. DSC graph of $\left[\mathrm{Fe}(\text { nor })_{2}\left(\mathrm{H}_{2} \mathrm{O}\right) \mathrm{Cl}\right] .5 \mathrm{H}_{2} \mathrm{O}$

\section{SEM studies}

Layers in the micrograph of $\left[\mathrm{Fe}(\text { nor })_{2}\left(\mathrm{H}_{2} \mathrm{O}\right) \mathrm{Cl}\right] .5 \mathrm{H}_{2} \mathrm{O}$ and $\left[\mathrm{Ni}(\text { nor })_{2}\left(\mathrm{H}_{2} \mathrm{O}\right)_{2}\right] .4 \mathrm{H}_{2} \mathrm{O}$ reveal that the system (Figure $3 \& 4$ ) contains atoms in a well-defined pattern. Thus reactants have reacted completely to form a clear homogenous compound. In general the SEM photograph shows single phase formation with well-defined grain like shape and particle size in the range of $0.5 \mu \mathrm{m}$.

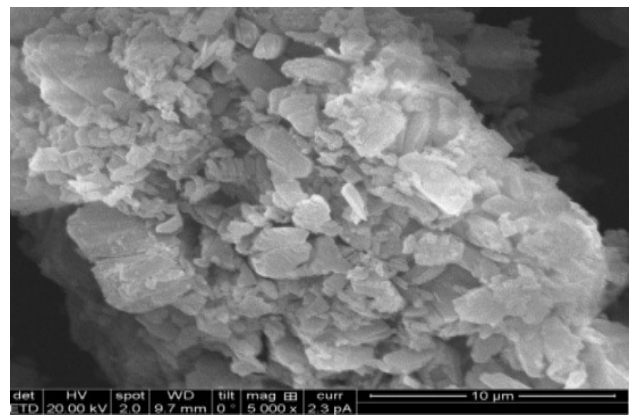

Figure 3. $\left[\mathrm{Fe}(\text { nor })_{2}\left(\mathrm{H}_{2} \mathrm{O}\right) \mathrm{Cl}\right] .5 \mathrm{H}_{2} \mathrm{O}$

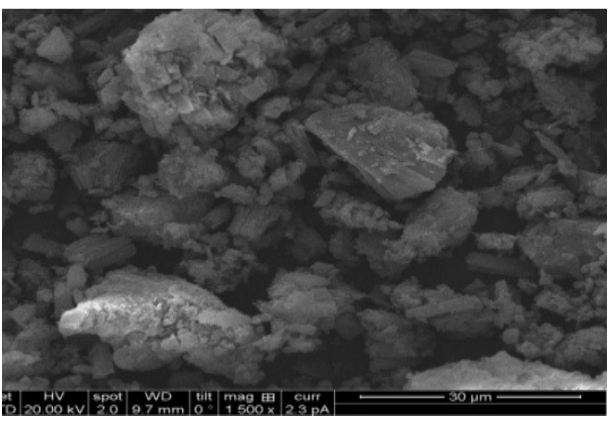

Figure 4. $\left[\mathrm{Ni}(\text { nor })_{2}\left(\mathrm{H}_{2} \mathrm{O}\right)_{2}\right] \cdot 4 \mathrm{H}_{2} \mathrm{O}$

\section{DNA binding studies by viscosity method}

Optical photophysical probes generally provide necessary, but insufficient clues to further clarify the interactions between the study complex and DNA. Hydrodynamic measurements that are sensitive to length change (i.e. viscosity and sedimentation) are regarded as the least ambiguous and the most critical tests of binding in solution in the absence of crystallographic structural data. A classical intercalation model demands that the DNA helix lengthens as base pairs are separated in order to accommodate the binding ligand, leading to an increase in DNA viscosity. In contrast, a partial, non-classical intercalation of compound could bend (or kink) the DNA helix, reducing its effective length and concomitantly, its viscosity ${ }^{26}$. Viscosity experiment results clearly show that both the compounds can intercalate between adjacent DNA base pairs, causing an extension in the helix, and thus increase the viscosity of DNA. The effects of increasing concentration of metal complexes of norfloxacin on the relative viscosity $\left(\eta / \eta_{0}\right)^{1 / 3}$ of DNA is shown in Figure 5. 


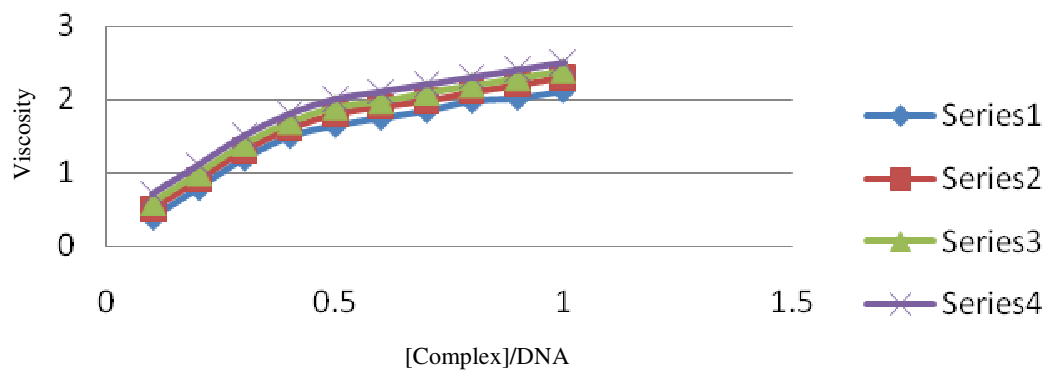

Figure 5. Effects of increasing concentration of metal complexes of norfloxacin on the relative viscosity $\left(\eta / \eta_{0}\right)^{1 / 3}$ of DNA

\section{Conclusion}

Mononuclear complexes of norfloxacin were haracteriz and haracterized by various physico-chemical techniques. The overall geometry around respective metal ions has been drawn on the basis of electronic spectral and magnetic moment studies. It is hoped that the synthesis of these complexes may be recommended for a new line of search for new antibiotics. From the spectral studies the proposed geometry of the complexis given in Figure 6.

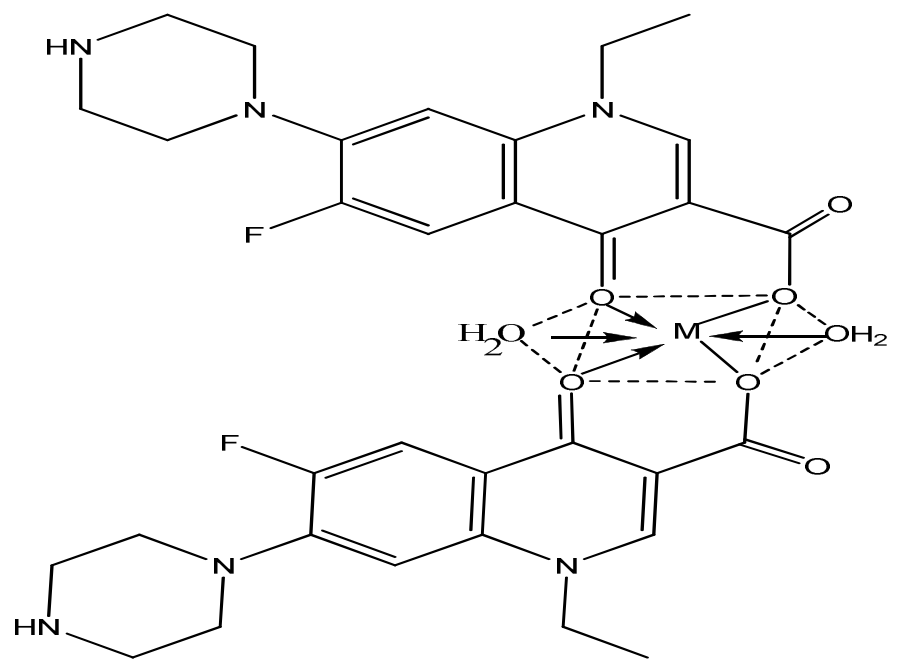

Figure 6. Geometry of copper complex of Norfloxacin, $\mathrm{M}=\mathrm{Cu}(\mathrm{II})$ ion

\section{Acknowledgement}

The author is thankful to the Chancellor, Noorul Islam Universityfor providing necessary research facilities.

\section{References}

1. $\quad$ Miller J M T H, J Clin Pathol., 1974, 27(10), 828-831; DOI:10.1136/jcp.27.10.828

2. $\quad$ Anacona J R, J Coord Chem., 2001, 54(3-4), 355-365; DOI:10.1080/00958970108022648

3. Lozano $\mathrm{M}$ J and Borras J, J Inorg Biochem, 1987, 31(3), 187-195; DOI:10.1016/0162-0134(87)80004-1 
4. Zhao A, Carraher C E, Barone G, Pellerito C, Scopelliti M and Pellerito L, Polym Mater Sci Engg, 2005, 93(25), 538-539.

5. Iqbal M S, Ahmad A R, Sabir M and Asad S M, J Pharm Pharmacol, 1999, 51(4), 371-375; DOI:10.1211/0022357991772556

6. Turel I, Leban I, Klintschar, Bukovec N and Zalar S, J Inorg Biochem., 1997, 66(2), 77-82; DOI:10.1016/S0162-0134(96)00157-2

7. Turel I, Gruber K, Leban H and Bukovec N, J Inorg Biochemi., 1996, 61(3), 197-212; DOI:10.1016/0162-0134(95)00056-9

8. Turel I, Leban I, Zupancic M, Bukovec N and Gruber K, Acta Cryst., 1996, 52, 2443-2445; DOI:10.1107/S0108270196005343

9. Chen Z F, Xiong R G, Zuo J L, Guo Z, You X Z, Fun H K, J Chem Soc., Dalton Trans., 2000, 4013-4014.

10. Al-Mustafa J, Acta Chimica Slovenica, 2002, 49(3), 457-466.

11. Ruız M, Perello L, Server-Carrio J, Ortiz R, Garcia-Granda S, Diaz M R and Cantón E, $J$ Inorg Biochem , 1998, 69(4), 231-239; DOI:10.1016/S0162-0134(97)10028-9

12. Cohen G and Eisenberg H, Biopolymers, 1969, 8(1), 45-55; DOI:10.1002/bip.1969.360080105

13. Geary W J, Coordin Chem Rev., 1971, 7(1), 81-122; DOI:10.1016/S00108545(00)80009-0

14. Sarkar S and Dey K, Spectro Chimica Acta, 2005, 62(1-3), 383-393; DOI:10.1016/j.saa.2005.01.005

15. Saeed Arayne, Najma Sultana, Urooj Haroon, Ahmed Mesaik, Bioinorg Chem Appl., Vol. 2009 (2009), Article ID 914105, 6 pages

16. Al-Kubais A.H and Ismail K.Z, Canadian J Chem., 1994, 72(8), 1785-1788.

17. Amendola V, Boiocchi M, Brega V, FabbrizziL and Mosca L, Inorga Chem., 2010, 49(3), 997-1007; DOI:10.1021/ic9019684

18. Lever A B P and Lewis J and Nyholm R S, J Chem Soc., 1963, 2552-2556.

19. Ballhausen C J, An Introduction to Ligand Field Theory, 1962.

20. Chowdhury H, Banerjee J, Rahaman H, Bose D and Ghosh B K, Indian J Chem., 2004, 43A(5), 2112-2118.

21. Hathaway B and Billing D E, Coordin Chem Rev., 1970, 5(2), 143-207; DOI:10.1016/S0010-8545(00)80135-6

22. Deacon G B and Phillips A D, Coordin Chem Rev., 1980, 33(3), 227-250; DOI:10.1016/S0010-8545(00)80455-5

23. El-Wahed M G A, Refat M.S and El-Megharbel S M, Spectrochimica Acta, 2008, 70(4), 911-916.

24. Holde V K E, Johnson C W and Ho S P, Principles Physical Biochemistry, 2006, 72-105.

25. Cooper A, Nutley M A and Wadood A, Differential Scanning Microcalorimetry, 2000, 287-318.

26. Satyanarayana S, James C D and Jonathan Chaires B, Biochem., 1993, 32(10), 25732584; DOI:10.1021/bi00061a015 